\title{
Interactive effects of irradiance and water availability on the photosynthetic performance of Picea sitchensis seedlings: implications for seedling establishment under different management practices
}

\author{
Kevin BlaCK*, Phill Davis, Joseph Mc Grath, Pat Doherty, Bruce Osborne \\ Botany Department, University College Dublin, Belfield, Dublin 4, Ireland
}

(Received 26 July 2004; accepted 3 March 2005)

\begin{abstract}
The impact of water availability on the photosynthetic performance of three year old, commercially obtained, Sitka spruce (Picea sitchensis) seedlings under exposed and shaded conditions was evaluated to provide a physiological understanding of the factors controlling seedling performance under conventional and continuous cover forestry (CCF) management scenarios. Decreases in photosynthesis in response to water deficits, under exposed and shaded conditions, were associated with reductions in both stomatal $\left(G_{\mathrm{s}}\right)$ and mesophyll conductance $\left(G_{\mathrm{m}}\right)$, and an increase in the proportion of electrons consumed in non-photosynthetic pathways. After re-watering, photosynthesis of plants subjected to higher irradiances was inhibited for up to 6 days due to high photorespiratory activity and damage to photosystem II. Waterlogged seedlings grown under both exposed and shaded conditions showed smaller decreases in photosynthesis that were also associated with an altered $G_{\mathrm{S}}$ and $G_{\mathrm{m}}$, but no changes in chlorophyll fluorescence related parameters were observed. We conclude that the performance of seedlings will be more susceptible to management-related or environmentally-induced water deficits in exposed sites typical of temperate latitudes and may, therefore, be improved in CCF systems.
\end{abstract}

continuous cover forestry / irradiance / water availability / photosynthesis

\begin{abstract}
Résumé - Interactions entre intensité lumineuse et disponibilité en eau sur la performance photosynthétique de plants de Picea sitchensis : implications sur le développement des plants selon leur différentes pratiques culturales. L'impact de la disponibilité en eau sur la performance photosynthétique de jeunes plants de Picea sitchensis, âgés de 3 ans d'origine commerciale sous conditions ensoleillées et ombragées fut évalué pour comprendre physiologiquement les facteurs contrôlant la performance des plants dans les conditions conventionnelles et de couvert forestier continu (continuous cover forestry, CCF). Les diminutions de la photosynthèse en réponse aux déficits hydriques sous conditions de plein ensoleillement et d'ombre étaient accompagnées de réductions des conductivités stomatique $\left(G_{\mathrm{s}}\right)$ et mésophyllienne $\left(G_{\mathrm{m}}\right)$ et d'une augmentation de la proportion d'électrons consommés par les activités non-photosynthétiques. Après réhydratation, la photosynthèse chez les plants soumis aux hautes intensités lumineuses restait limitée jusqu'à 6 jours à cause de l'importante activité photorespiratoire et des dommages subits par le PSII. En conditions inondées, les plantules cultivées sous ensoleillement et à l'ombre présentèrent de moindres réductions de leur photosynthèse qui étaient associées à des modifications de $G_{\mathrm{s}}$ et $G_{\mathrm{m}}$, mais sans changement des paramètres de la fluorescence chlorophyllienne. Nous en concluons que la performance des plants est plus sensible aux déficits hydriques liés à la pratique culturale ou aux conditions environnementales dans les sites ensoleillés typiques des latitudes tempérées et peut donc être amélioré par l'emploi de systèmes CCF.
\end{abstract}

couvert forestier continu / intensité lumineuse / disponibilité en eau / photosynthèse

\section{INTRODUCTION}

There is currently a growing interest in the introduction of continuous cover forestry (CCF) management systems to reduce the adverse environmental effects normally associated with conventional patch clearfelling and replanting methods. These CCF approaches generally include restocking by natural regeneration or under-planting within existing stands [12]. In both cases, successful seedling establishment will depend on how stand management influences the environmental conditions beneath the existing canopy. An important management issue in CCF is the trade-off between successful seedling establishment, which is dependent on the amount of light reaching the forest floor and windthrow risk associated with thinning operations [14]. Although the light environment is regarded as an important limitation for seedling establishment in CCF systems [12] other related factors, such as water availability, may also be significant $[32,33]$. Under varying light conditions, a

\footnotetext{
*Corresponding author: kevin.black@ucd.ie
} 
combination of different environmental factors causes an intensification, overlapping or reversal of the impact of water availability $[16,33]$. This suggests a complex relationship between water availability, irradiance and seedling establishment. Whilst there is good evidence that the impact of water deficits on seedling establishment is exacerbated under high irradiances $[9,32]$, this would depend on the acclimation ability and light requirements of different species [31, 32]. Although the impacts of water deficits may be less under shaded conditions, because of a lower evaporative demand, the amount of soil water available to understory plants is likely to be reduced due to competition for water by surrounding mature trees and interception of rainfall by the canopy.

The interaction between irradiance and water availability is particularly relevant to the establishment of out-planted seedlings in CCF compared to clearfell/re-forestation management systems. The impact of water deficits could also be exacerbated due to the out-planting of bare-root seedling stock, as is used in Ireland and the UK, in the early spring [24]. The shallow rooting pattern of Sitka spruce in wet mineral soils [22] may render seedlings more susceptible to transient water deficits that are typically experienced between April and July [21]. Conversely, water logging, particularly in poorly drained wet mineral gley soils [22], also influences seedling survival and growth following out-planting [22]. Under field conditions both scenarios are likely to arise, so seedling performance may depend on an ability to respond to both water deficits and water logging during an annual growth cycle.

Assessments of photosynthetic performance provides a useful means of monitoring the response of seedlings to a number of environmental factors, since photosynthesis is sensitive to changes in temperature, water availability and irradiance [25]. A decrease in stomatal aperture is the major factor contributing to reductions in water loss during periods of high evaporative demand, but this will also reduce photosynthesis due to decreases in intracellular $\mathrm{CO}_{2}$ concentrations, under both water limited and waterlogged conditions $[9,27]$. Photosynthesis would also be inhibited due to the increased participation of competing pathways and consumption of electrons and reductant in nonphotosynthetic processes [34]. Reductions in stomatal conductance $\left(G_{\mathrm{s}}\right)$ in response to water deficits may also enhance the sensitivity of the photosynthetic apparatus to high irradiances, leading to photodamage to photosystem II [25]. Another potential limitation is the diffusion of $\mathrm{CO}_{2}$ from the intracellular spaces within leaves to the sites of carboxylation in the chloroplast (mesophyll conductance $\left(G_{\mathrm{m}}\right)$ ). However, the relative contribution of these diffusive path limitations to a combination of environmental factors such as, light, water deficits or water logging, are still poorly understood.

In this study, the physiological status of three-year-old Sitka spruce seedlings, obtained from a commercial nursery and subjected to differences in water availability was assessed in a glasshouse under exposed and shaded conditions. The primary aim was to examine the impact of interactions between water availability and irradiance in order to provide a more comprehensive understanding of the constraints associated with Sitka spruce seedling establishment under different management systems.

\section{MATERIALS AND METHODS}

\subsection{Plant material and experimental design}

Picea sitchensis (Bong. (Carr.)) seedlings were grown in fumigated beds in Ballinatemple Nursery $\left(52^{\circ} 44^{\prime} \mathrm{N}, 6^{\circ} 42^{\prime} \mathrm{W}, 100\right.$ m elevation) Co. Carlow, Ireland. The mean annual rainfall for 1999 to 2002 recorded near the site was $904 \mathrm{~mm}$, with a mean minimum and maximum temperature of 5.3 and $14.1^{\circ} \mathrm{C}$, respectively and an average relative humidity of $79 \pm 8 \%$. The annual mean integrated daily irradiance for 1999 to 2002 was $9.8 \pm 6 \mathrm{~mol} \mathrm{~m}^{-2}$ day $^{-1}$ (Met Èireann). The nursery soil is a sandy loam ( $\mathrm{pH}$ 5.7) with an organic matter content of $\sim 10 \%$ and sand, silt and clay fractions of 66,19 and $15 \%$ respectively.

Seedlings used in this study received identical treatments to those used in normal planting programme. Plants received monthly additions of nitrogen $\left(14 \mathrm{~kg} \mathrm{ha}^{-1}\right)$ from April to July, with top dressings of $\mathrm{K}$ and $\mathrm{Mg}$ in July. In early February 2003, three year old, bare root seedling stock ( 0.5 to $0.6 \mathrm{~m}$ high) was lifted by hand and transported in poly-urethane coextruded bags to University College Dublin. Seedlings were planted into pots $\left(1200 \mathrm{~cm}^{3}\right)$ containing peat moss (Erin Sphagnum Peat Moss) and subsequently grown in a greenhouse under conditions similar to the ambient environment, except that water availability and irradiance was manipulated. Half of the seedlings ( 24 pots) were placed under $50 \%$ shade cloth while the other seedlings were left fully exposed. Soil moisture was initially maintained at $\sim 0.7 \mathrm{~cm}^{3} \mathrm{~cm}^{-3}$ (v/v) by monitoring soil water content using a Theta soil moisture probe (Delta-T Devices, Cambridge, UK) and watering pots every 1-2 days. Seedlings were initially acclimatised for 8 weeks and all measurements were made on shoots that had developed under the sun/ shade conditions in an effort to account for ontogenetic variation between seedlings.

After the acclimatisation period a total of 8 seedlings per treatment were arranged in a randomised block design containing 2 light treatments (50\% shade and full sunlight) and 3 water treatments (well watered, no watering, and waterlogged). For the well-watered (control) seedlings, soil moisture content was kept at $0.7 \mathrm{~cm}^{3} \mathrm{~cm}^{-3}$. Watering was withheld for a period of 2 weeks followed by re-watering to a constant soil moisture content of $0.7 \mathrm{~cm}^{3} \mathrm{~cm}^{-3}$. For the waterlogged treatments, the pots were placed into a larger sealed pot completely filled with water to saturate the soil for the 25-day duration of the experiment.

\subsection{Microclimate measurements}

Air vapour pressure deficits (VPD) under exposed and shaded conditions were calculated using measured air temperature and humidity, recorded every 30 min with a SKH 2001/I sensor and Data Hog 2 logger (Skye Instruments, Powys, UK). Photosynthetically active radiation $(\lambda=400-700 \mathrm{~nm})$ under the fully exposed and $50 \%$ shade treatments was recorded every 30 min using a Syke PAR sensor (SKP 215/I, Skye Instruments, Powys, UK). Midday volumetric soil moisture content was recorded every 2-3 days and when photosynthetic measurements were made.

\subsection{Gas exchange and steady state chlorophyll fluorescence measurements}

All measurements were made on shoots that had emerged and developed under the different light environments. Gas exchange measurements were made on fully expanded shoots on whorl one of each plant using a CIRAS 1 infra red gas analyser and a Parkinson conifer curvette with climate control (Model PLCc; PP Systems, Hitchin, Herts, England). Water and $\mathrm{CO}_{2}$ exchange rates were expressed on a projected shoot area basis. Images of projected shoot area were captured using a flat bed scanner and their area determined using Scion Imaging Software (Beta 4.0.1, Scion Corporation, Maryland, USA). 
On the 1st, 7th, 14th and 21 st day after initiation of the water treatments, individual photosynthetic light response curves for each treatment were determined. Photosynthetic light response curves $(0$ $800 \mu \mathrm{mol}$ photon $\mathrm{m}^{-2} \mathrm{~s}^{-1}$ ) were measured using an external $\mathrm{CO}_{2} \mathrm{con}$ centration $\left(C_{\mathrm{a}}\right)$ of $350 \mu \mathrm{mol} \mathrm{mol}{ }^{-1}$, at $15^{\circ} \mathrm{C}( \pm 2.5)$. Photosynthetic light response parameters were determined using a non-linear least squares optimisation of the following light response function [18];

$\theta\left(A-R_{\mathrm{n}}\right)^{2}-\left(I . \varnothing+A_{\max }\right)\left(A-R_{\mathrm{n}}\right)+\varnothing . I . A_{\max }=0$

where $\mathrm{A}$ is the net photosynthetic rate at a given incident irradiance $(I), \theta$ is the convexity of the curve, $\varnothing$ is the photon yield based on incident irradiance, $R_{\mathrm{n}}$ is the dark respiration rate and $A_{\max }$ the maximum net photosynthetic rate.

Chlorophyll fluorescence determinations were made on the same shoots as those used for gas exchange measurements, with a modulated fluorometer (FMS 2, Hanstech Instruments Ltd, Norfolk, England). The conifer curvette was modified to accommodate the fluorescence probe so that simultaneous photosynthetic and chlorophyll fluorescence measurements could be made. Shoots were dark adapted for $30 \mathrm{~min}$ prior to measurement. The protocol for fluorescence measurements was an initial $0.7 \mathrm{~s}$ pulse of saturating irradiance $(6400 \mu \mathrm{mol}$ photon $\mathrm{m}^{-2} \mathrm{~s}^{-1}$, at a wavelength of $685 \mathrm{~nm}$ ) to determine the potential (dark adapted) quantum yield of Photosystem II $\left(F_{\mathrm{v}}^{\mathrm{o}} / F_{\mathrm{m}}^{\mathrm{o}}\right)$. After a recovery period of $45 \mathrm{~s}$ in the dark, a continuous actinic source (200 $\mu \mathrm{mol}$ photon $\mathrm{m}^{-2} \mathrm{~s}^{-1}$ ) was applied along with saturating pulses of light (every $10 \mathrm{~s}$ ) for 5 min to determine steady state maximal fluorescence in the light $\left(F_{\mathrm{m}}\right.$ ). The actinic source was then switched off after the final saturating pulse, followed by a pulse $(1 \mathrm{~s})$ of far-red light $(750 \mathrm{~nm})$ to determine the minimal fluorescence value in the lightadapted state $\left(F_{\mathrm{o}}^{\prime}\right)$.

The light adapted photon yield of Photosystem II ( $\varnothing \mathrm{PSII})$ and the estimated rate of electron transport via Photosystem II (ETR $P S I I)$ were calculated [11];

$$
\emptyset \mathrm{PSII}=\left(F_{\mathrm{m}}-F_{\mathrm{t}}\right) / F_{\mathrm{m}}
$$

where $F_{\mathrm{t}}$ is the steady state minimal fluorescence in the light before the saturating pulse is applied to the shoot. The electron transport rate was then calculated from;

$$
\operatorname{ETR}_{P S I I}=\alpha \cdot 0.5 . I_{\mathrm{O}} \cdot \emptyset \mathrm{PSII} .
$$

In this equation $\alpha$ is the absorptance by shoots ( 0.83 to 0.86 ), as measured with an integrating sphere, 0.5 is the proportion of photons partitioned to PSII and $I_{\mathrm{O}}$ is the incident irradiance.

The proportion of electrons that are dissipated through processes other than photosynthetic carboxylation of $\operatorname{RuBP}\left(P_{\text {diss }}\right)$, mainly photorespiration, was estimated using the equation [33];

$$
P_{\text {diss }}=\left(E T R_{P S I I}-4 A_{\text {gross }}\right) / E R_{P S I I}
$$

where $A_{\text {gross }}=A+R_{\mathrm{n}}$. The dissipation of electrons via non-photosynthetic processes was calculated using $R_{\mathrm{n}}$ instead of mitochondrial respiration in the light $\left(R_{\mathrm{d}}\right)$. It has been suggested that $R_{\mathrm{n}}$ may be an erroneous estimate of $R_{\mathrm{d}}$, which is inhibited by light by 16 to $77 \%$ [10]. However, when $P_{\text {diss }}$ was derived using the most extreme variations in $R_{\mathrm{d}}$ (i.e. $R_{\mathrm{d}}=R_{\mathrm{n}}$ and $\left.R_{\mathrm{d}}=R_{\mathrm{n}} .0 .33\right) P_{\text {diss }}$ only varied by $\sim 10 \%$ (also see [33]).

Estimates of mesophyll conductance $\left(G_{m}\right)$ were calculated using data from simultaneous measurements of net photosynthesis versus internal $\mathrm{CO}_{2}$ concentration $\left(A / C_{i}\right)$ and chlorophyll fluorescence using equation 5 [15]:

$$
G_{m}=\frac{A}{C_{i}-\frac{\Gamma^{*} \cdot\left[E T R_{\phi P S I I}+8 \cdot\left(A+R_{d}\right)\right]}{E T R_{\phi P S I I}-4 .\left(A+R_{d}\right)}}
$$

where $C_{\mathrm{i}}$ is the internal $\mathrm{CO}_{2}$ concentration, $\Gamma^{*}$ is the $\mathrm{CO}_{2}$ compensation point in the absence of mitochondrial respiration and $R_{\mathrm{d}}$ is mitochondrial respiration in the light. The values for $\Gamma^{*}$ for Sitka spruce were taken from the literature [36] and the temperature dependent variations in $\Gamma^{*}$ were calculated as described previously [3]. Dark respiration rate was first measured as an estimate of $R_{\mathrm{d}}$ followed by simultaneous photosynthetic and $\varnothing$ PSII measurements over a range of ambient $\mathrm{CO}_{2}$ concentrations $\left(0\right.$ to $\left.1500 \mu \mathrm{mol} \mathrm{mol}^{-1}\right)$ under saturating light $\left(200 \mu \mathrm{mol}\right.$ [photon] $\left.\mathrm{m}^{-2} \mathrm{~s}^{-1}\right)$.

\subsection{Relaxation analysis of fluorescence quenching}

To partition non-photochemical quenching (NPQ) into fast and slow processes, relaxation analysis of $N P Q$ following illumination was performed [35]. $F_{\mathrm{v}}^{\mathrm{o}} / F_{\mathrm{m}}^{\mathrm{o}}$ and $F_{\mathrm{m}}^{\prime}$ were determined using the protocol from the previous section. Following the exposure to actinic light (200 $\mu \mathrm{mol}$ [photon] $\mathrm{m}^{-2} \mathrm{~s}^{-1}$ ), shoots were allowed to recover in the dark and exposed to a saturating pulses $\left(6400 \mu \mathrm{mol}\right.$ photon $\mathrm{m}^{-2} \mathrm{~s}^{-1}$, at a wavelength of $685 \mathrm{~nm}$ ) of white light at 2, 5, 10,15,20,30 and 45 min after the actinic light had been switched off. The values of the $\log$ of maximal fluorescence, during the dark recovery, were plotted against time and extrapolations were made from the end of the relaxation curve (i.e., data points at $20-45 \mathrm{~min}$ ) back to the point where the actinic light was removed. This value represents the maximal fluorescence attained through slow relaxing quenching processes $\left(F_{\mathrm{m}}^{\mathrm{r}}\right)$. The slow $\left(N P Q_{\mathrm{S}}\right)$ and fast $\left(N P Q_{\mathrm{F}}\right)$ relaxing quenching values were then calculated using the following formulae [35];

$$
\begin{gathered}
N P Q_{\mathrm{S}}=\left(F_{\mathrm{m}}^{\mathrm{o}}-F_{\mathrm{m}}^{\mathrm{r}}\right) / F_{\mathrm{m}}^{\mathrm{r}} \\
N P Q_{\mathrm{F}}=\left(F_{\mathrm{m}}^{\mathrm{o}} / F_{\mathrm{m}}^{\prime}\right)-\left(F_{\mathrm{m}}^{\mathrm{o}}-F_{\mathrm{m}}^{\mathrm{r}}\right) .
\end{gathered}
$$

\subsection{Diurnal gas exchange, chlorophyll fluorescence, shoot water potential and hydraulic conductance determinations}

Dark respiration rates, $A_{\max }$ and leaf water status at a saturating irradiance $\left(200 \mu \mathrm{mol}\right.$ photon $\left.\mathrm{m}^{-2} \mathrm{~s}^{-1}\right)$ were determined at predawn and midday (1100-1400 GMT) to account for diurnal variations in photosynthesis in response to water deficits $[32,33]$. Predawn photosynthetic parameters were measured on shoots from seedlings that had been covered the previous evening with black coextruded poly-urethene bags.

After the gas exchange measurements shoot water potentials were measured using a Scholander Pressure Bomb (Model 140, Skye Instruments, Powys, UK). Pre-dawn shoot $\left(\Psi_{\text {pre-dawn }}\right)$ and soil water potentials are assumed to be in equilibrium before sunrise, therefore, these measurements were considered to be equivalent to the substrate water potential [28]. Midday shoot water potential $\left(\Psi_{\text {midday }}\right)$ and photosynthetic measurements were repeated on similar shoots from the same seedlings between 1100 and 1400 GMT. Hydraulic conductance $\left(H_{c}\right)$ at midday was estimated using measurements of $\Psi_{\text {pre-dawn }}$ ( soil $\Psi$ ), $\Psi_{\text {midday }}$ and transpiration rates $(E)$ under saturating light levels using the following formula [23]:

$$
H_{\mathrm{c}}=E /\left(\Psi_{\text {pre-dawn }}-\Psi_{\text {midday }}\right) \text {. }
$$

\section{RESULTS}

\subsection{The microclimate under exposed and shaded conditions}

Daily insolation and half-hourly irradiances recorded over the duration of the experiment (Figs. 1c and 1e), combined with 


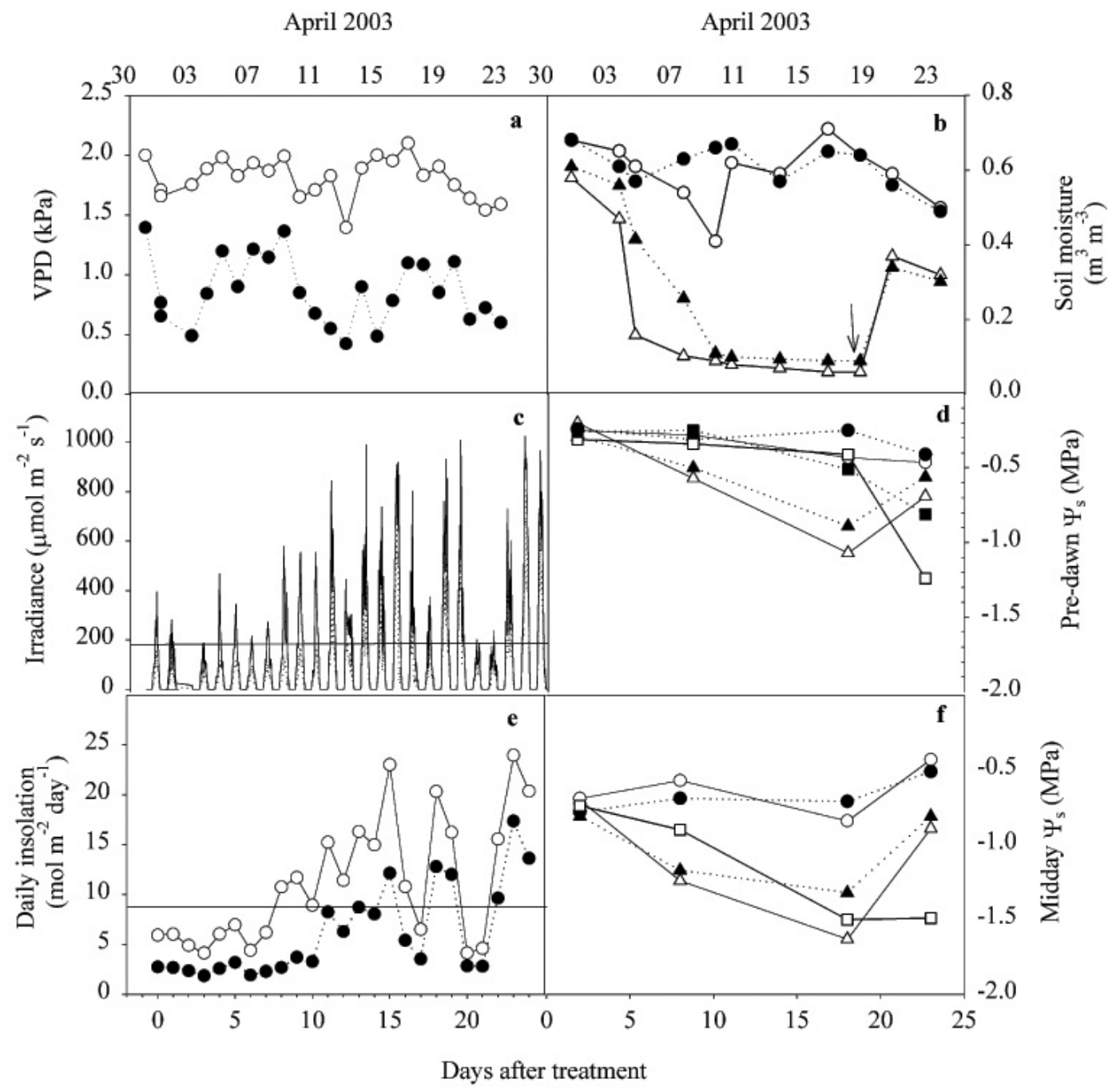

Figure 1. Fluctuations in vapour pressure deficit (a, VPD), irradiance $(\mathbf{c}, \lambda=400-700 \mathrm{~nm})$, daily isolation (e), soil moisture (b), predawn (d) and midday $(\mathbf{f})$ shoot water potentials $\left(\Psi_{\mathrm{S}}\right)$. The solid lines with open symbols and broken lines with closed black symbols represent seedlings grown under full sunlight and 50\% shade, respectively. Water treatments are indicated by different symbols, where circles are the control, triangles are the water deficit and squares are the water logged seedlings. The solid horizontal line in panels (c) and (e) represents the mean light saturation point for both sun and shaded seedlings. The arrow in panel (b) indicates when seedlings subject to water deficits (triangles) were re-watered.

measurements of the light saturation point $\left(L_{s}\right)$ for photosynthesis (Tab. I), indicated that for $43-56 \%$ of the day light hours shoots in the exposed treatments would be subjected to saturating irradiances. In contrast, shoots in the shade treatment were subjected to saturating light for only $24 \%$ of the time (Fig. 1e). Vapour pressure deficits (VPD) were $\sim 30 \%$ lower in the shaded, compared to the fully exposed treatment, for the duration of the experiment (Fig. 1a).

\subsection{Acclimation of seedlings to the different light environments}

Before plants were subjected to the different watering treatments (Fig. 1), there were no differences in the apparent photon yield $\left(\varphi_{i}\right)$, light compensation point $\left(L_{c}\right)$, light saturation point $\left(L_{s}\right)$ or maximum photosynthetic rate $\left(A_{\max }\right)$ of shoots from the fully exposed or $50 \%$ shade treatment (Tab. I). The potential quantum yield of PSII $\left(F_{\mathrm{v}}^{\mathrm{o}} / F_{\mathrm{m}}^{\mathrm{o}}\right)$ and the light-adapted photon yield of PSII ( $\varnothing$ PSII) were similar for both sun and shade plants (Tab. I).

\subsection{The effect of water deficits on photosynthesis and leaf conductance in exposed and shaded plants}

Over the first 7 days after the cessation of watering, exposed seedlings were initially subjected to a more rapid decline in volumetric soil moisture content and shoot water potentials $\left(\Psi_{\mathrm{S}}\right)$, when compared to shade treatments (Figs. $1 \mathrm{~b}$ and 1f). However, the volumetric soil moisture content was similar $\left(\sim 0.05 \mathrm{~m}^{3} \mathrm{~m}^{-3}\right)$ for both the exposed and shaded treatments after 7 to 15 days. When seedlings were re-watered the volumetric soil moisture contents and $\Psi_{\mathrm{S}}$ recovered in both the exposed and shaded plants (Figs. 1b, 1d and 1f). 


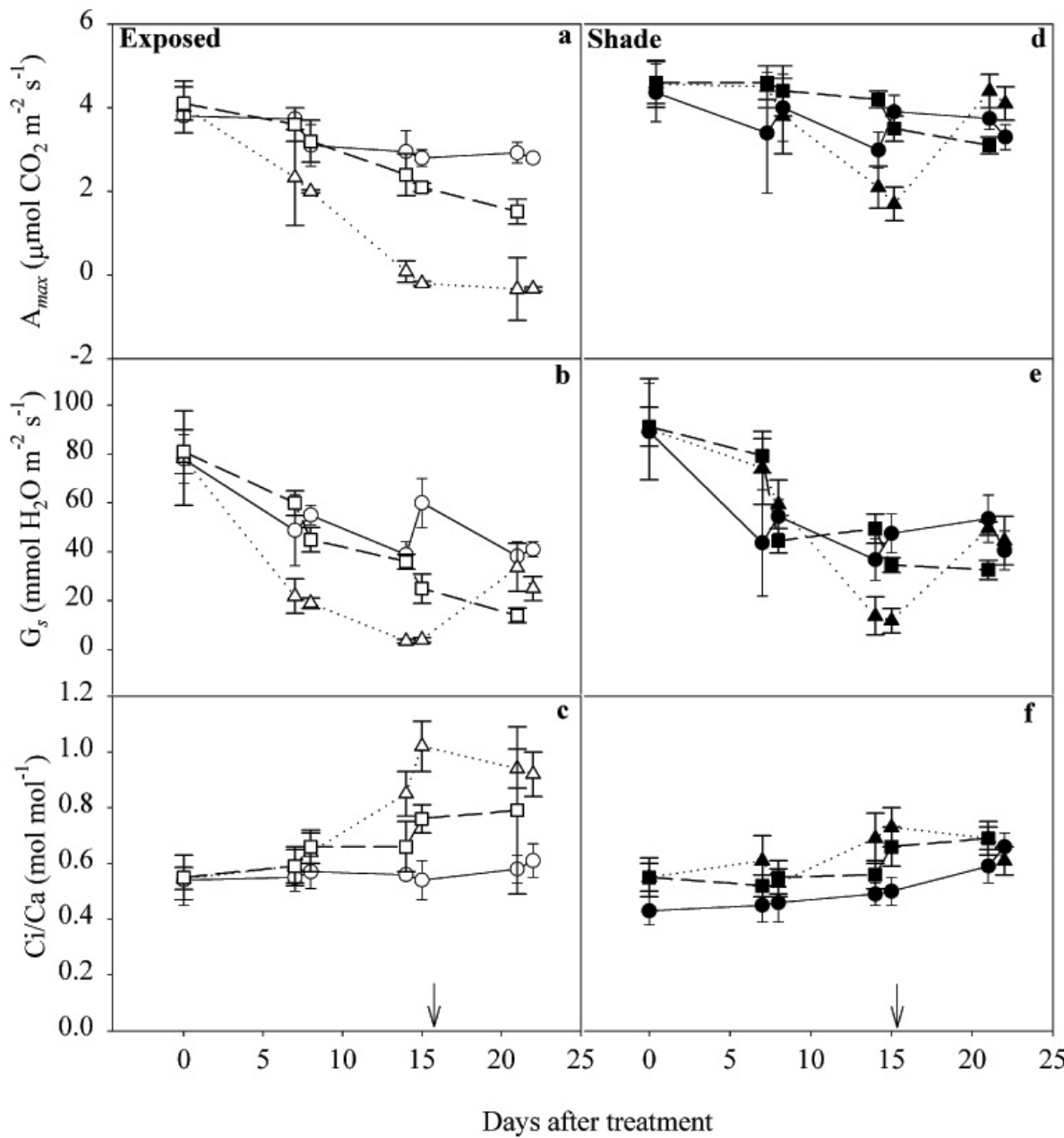

Figure 2. Variation in maximum photosynthetic rate $\left(A_{\max }\right)$, stomatal conductance $\left(G_{S}\right)$ and the ratio of internal to ambient $\mathrm{CO}_{2}$ concentration $\left(C_{\mathrm{i}} / C_{\mathrm{2}}\right)$ for shoots from control (circles), water deficit (triangles) and water logged (squares) treatments fully exposed (open symbols) or at $50 \%$ shade (closed symbols). Symbols represent a mean and vertical bars the standard deviation $(n=3)$. All measurements were made between 11:00 and 14:00. The arrows in panels (c) and (f) indicate when seedlings subjected to a water deficit (triangles), were re-watered.

Table I. Photosynthetic light response and chlorophyll fluorescence characteristics of shoots that had been either fully exposed or received $50 \%$ shade for a period of 8 weeks. All measurements were made on shoots that had emerged and developed under the different light environments during the 8-week period and prior to the onset of the water treatments. There were no significant differences $(P<0.05)$ between the values (mean \pm S.E., $n=9$ ) from the two treatments.

\begin{tabular}{|c|c|c|c|}
\hline \multirow[t]{2}{*}{ Parameter } & \multirow[t]{2}{*}{ Units } & \multicolumn{2}{|c|}{ Treatment } \\
\hline & & Full sunlight & $50 \%$ shade \\
\hline$\overline{R_{\mathrm{n}}}$ & $\mu \mathrm{mol}\left[\mathrm{CO}_{2}\right] \mathrm{m}^{-2} \mathrm{~s}^{-1}$ & $0.72 \pm 0.2$ & $0.65 \pm 0.12$ \\
\hline$A_{\max }$ & $\mu \mathrm{mol}\left[\mathrm{CO}_{2}\right] \mathrm{m}^{-2} \mathrm{~s}^{-1}$ & $4.5 \pm 0.8$ & $4.9 \pm 0.6$ \\
\hline$\varphi_{i}$ & $\operatorname{mol}\left[\mathrm{CO}_{2}\right] \mathrm{mol}^{-1}$ [photon] & $0.036 \pm 0.009$ & $0.038 \pm 0.011$ \\
\hline$L_{c}$ & $\mu \mathrm{mol}$ [photon] $\mathrm{m}^{-2} \mathrm{~s}^{-1}$ & $25 \pm 6$ & $27 \pm 4$ \\
\hline$L_{S}$ & $\mu \mathrm{mol}$ [photon] $\mathrm{m}^{-2} \mathrm{~s}^{-1}$ & $202 \pm 15$ & $191 \pm 21$ \\
\hline$\theta$ & - & $0.76 \pm 0.04$ & $0.78 \pm 0.06$ \\
\hline$F_{\mathrm{v}}^{\mathrm{o}} / F_{\mathrm{m}}^{\mathrm{o}}$ & - & $0.79 \pm 0.02$ & $0.81 \pm 0.02$ \\
\hline$\varnothing \mathrm{PSII}$ & - & $0.35 \pm 0.01$ & $0.37 \pm 0.02$ \\
\hline
\end{tabular}

$R_{\mathrm{n}}$ is respiration rate in darkness, $A_{\max }$ is the light saturated photosynthetic rate, $\varphi_{i}$ is the photon yield on an incident light basis, $L_{c}$ is the light compensation point, $L_{s}$ is the light level at which photosynthesis is saturated, $\theta$ is the convexity of the light response curve, $F_{\mathrm{v}}^{\mathrm{O}} / F_{\mathrm{m}}^{\mathrm{O}}$ is the potential (dark-adapted) quantum efficiency of Photosystem II $\left(F_{\mathrm{v}}^{\mathrm{o}} / F_{\mathrm{m}}^{\mathrm{o}}\right)$ and $\varnothing \mathrm{PSII}$ is the light-adapted photon yield of Photosystem II.

Water deficits resulted in a greater decline in $A_{\text {max }}$, maximum stomatal conductance $\left(G_{S}\right)$ and hydraulic conductance $\left(H_{c}\right)$ under exposed, compared to the shaded conditions (Figs. 2 and 3). The greater decline in $G_{S}$ in exposed seedlings subjected to water deficits (Figs. 2 and 3) was primarily associated with a higher leaf to air VPD (Fig. 1). After 2 weeks of water deficits, 


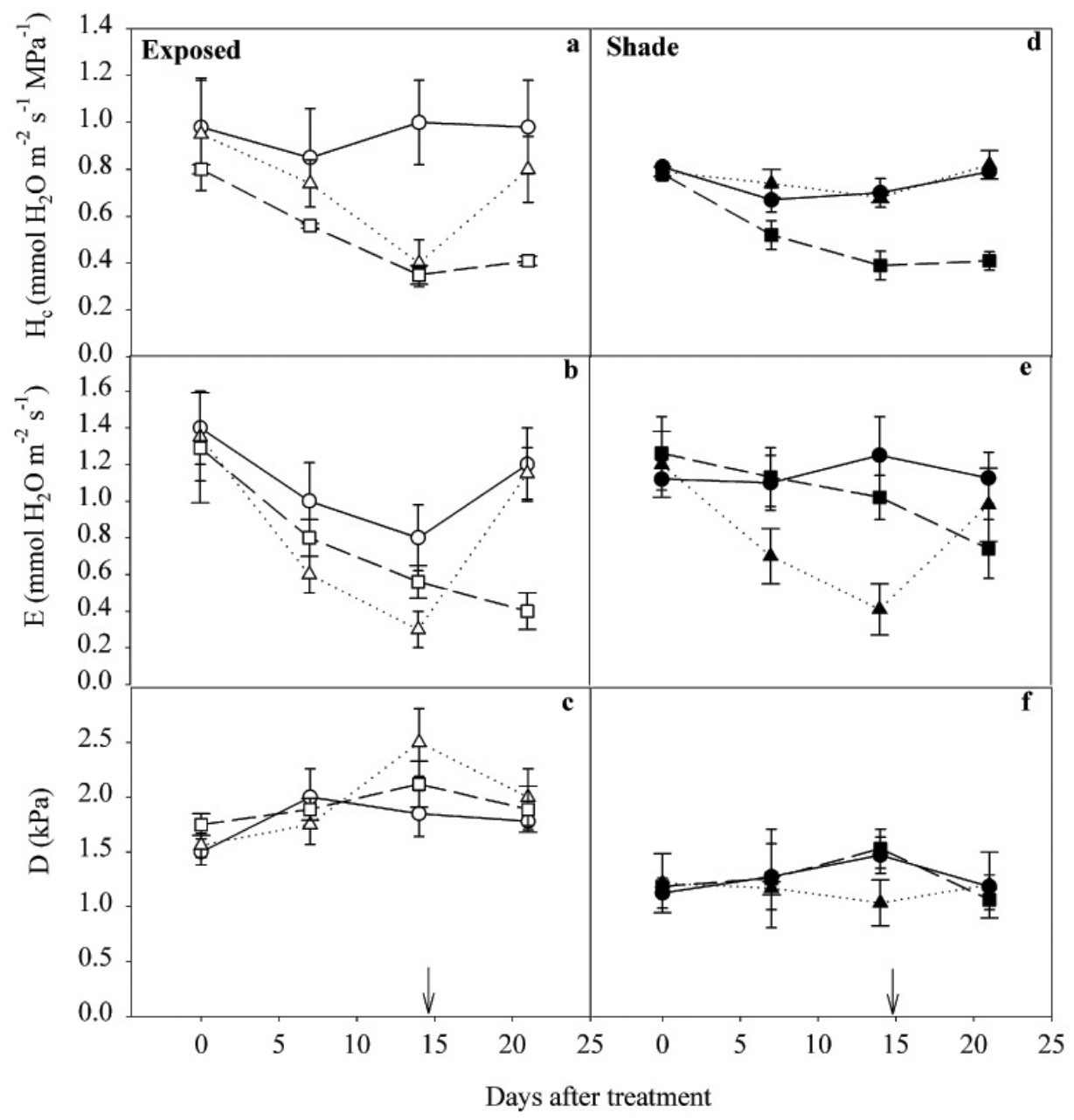

Figure 3. Variation in hydraulic conductance $\left(H_{c}\right)$, transpiration rates $(E)$ and leaf to air vapour pressure deficits $(D)$ for shoots from control (circles), water deficit (triangles) and water logged (squares) treatments grown under full exposure (open symbols) or 50\% shade (closed symbols). Symbols represent a mean and vertical bars the standard deviation $(n=3)$. All measurements were made between 11:00 and 14:00. The arrows in panels (c) and (f) indicate when seedlings subjected to a water deficit (triangles), were re-watered.

the exposed plants exhibited no uptake of $\mathrm{CO}_{2}$, while shaded plants had a reduced net photosynthetic rate (Figs. $2 \mathrm{a}$ and $2 \mathrm{~b}$ ). Estimates of mesophyll conductance $\left(G_{m}\right)$ were lower than $G_{\mathrm{S}}$, particularly in seedlings exposed to water deficits (Fig. 4). $G_{m}$ could not be estimated for the exposed plants subjected to water deficits for longer than a week because seedlings exhibited no net $\mathrm{CO}_{2}$ uptake after this period (Figs. 2 and 4).

After re-watering, $G_{\mathrm{S}}, G_{m}$, predawn and midday $\Psi_{\mathrm{S}}$ increased to a level comparable to the control plants for the exposed and shaded treatments (Figs. 2 and 4). While $A_{\max }$ for the shaded seedlings showed a recovery after re-watering, photosynthesis was still inhibited in the exposed seedlings after 6 days (Fig. 2).

\subsection{The effect of water logging on photosynthesis and leaf conductance in exposed and shaded plants}

The reduction in $A_{\max }$ in exposed and shaded seedlings under waterlogged conditions was also associated with a reduc- tion in $G_{s}, G_{m}, H_{\mathrm{c}}$ and $\Psi_{\mathrm{s}}$ (Figs. 1-4). The magnitudes of these changes were smaller when compared to the water deficit treatments. The decrease in $G_{s}$ under waterlogged conditions was greater in the exposed, compared to shaded plants, and was associated with a larger leaf to air VDP, and a lower midday $\Psi_{\mathrm{s}}$ and $H_{\mathrm{c}}$ (Figs. 1-3).

In contrast to the plants subjected to water deficits, the reduction in $H_{\mathrm{c}}$ in waterlogged seedlings was associated with a lower pre-dawn $\Psi_{\mathrm{S}}$ (proxy for soil water potential) and not a reduction in $G_{S}$ (Figs. 1-3).

\subsection{Photodamage to PSII and dissipation of excess energy}

Seedlings exposed to full sunlight showed a decrease in the potential quantum efficiency of photosystem II $\left(F_{\mathrm{v}}^{\mathrm{o}} / F_{\mathrm{m}}^{\mathrm{o}}\right)$, but this was more evident in the seedlings subjected to a water deficit from 2 weeks after withholding water (Fig. 5a). Although 


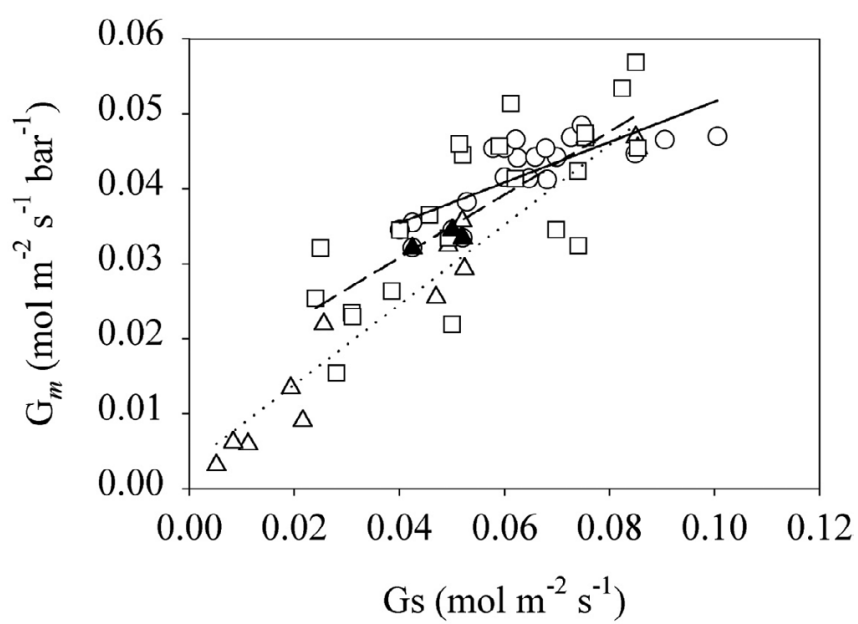

Figure 4. The relationship between mesophyll $\left(G_{m}\right)$ and stomatal conductance $\left(G_{S}\right)$ in control (circles), water logged (squares) and water deficit (triangles) treatments. Comparisons of $G_{s}$ and $G_{m}$ were made at 1 bar. The recovery of $G_{s}$ and $G_{m}$ following re-watering is illustrated by the black triangle. The linear regression for the control (solid line), water logged (dashed line) and water deficit (dotted line) treatments were all significant, $P<0.05$. exposed seedlings received an above saturating irradiance for 43 to $56 \%$ of the time (Fig. 1), these plants did not show any increase in fast non-photochemical quenching processes (Fig. 5c). After the induction of non-photochemical quenching at a given irradiance (above the light saturation point), dark recovery and relaxing quenching kinetic analysis showed that fast non-photochemical quenching $\left(N P Q_{\mathrm{F}}\right)$ decreased when exposed seedlings were subjected to water deficits for a 2 week period (Fig. 5c). The increase in slow non-photochemical quenching processes $\left(N P Q_{\mathrm{S}}\right)$ in the exposed seedlings that were well watered was associated with a decrease in $F_{\mathrm{v}}^{\mathrm{o}} / F_{\mathrm{m}}^{\mathrm{o}}$ (Figs. 5a and 5c). When exposed seedlings were re-watered, $N P Q_{\mathrm{S}}$ decreased to a level comparable with the well-watered seedlings. However, $F_{\mathrm{v}}^{\mathrm{o}} / F_{\mathrm{m}}^{\mathrm{o}}$ did not recover completely after exposed seedlings were re-watered (Fig. 5). Seedlings in the shaded and waterlogged treatments showed no change in either $F_{\mathrm{v}}^{\mathrm{o}} / F_{\mathrm{m}}^{\mathrm{o}}$ or non-photochemical quenching processes.

\subsection{Non-photosynthetic electron transport}

When exposed seedlings were subjected to water deficits the relative non-photosynthetic electron transfer rate $\left(P_{\text {diss }}\right)$ increased from 0.2 to 0.6 after 1 week (Fig. 6). When seedlings were re-watered, $P_{\text {diss }}$ did not decrease despite the full recovery

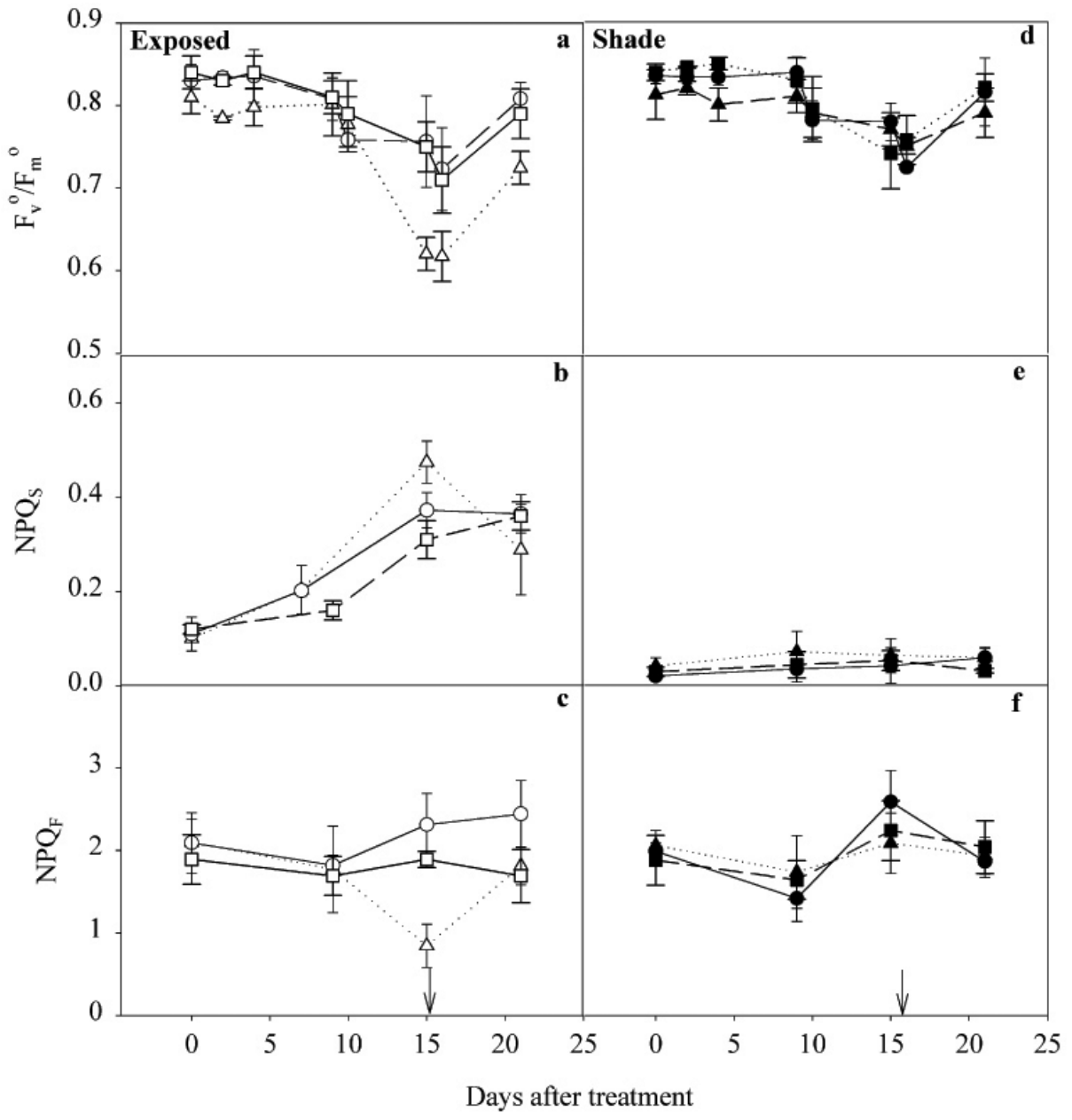

Figure 5. Variation in the potential (dark-adapted) quantum efficiency of Photosystem II $\left(F_{\mathrm{v}}^{\mathrm{o}} / F_{\mathrm{m}}^{\mathrm{o}}\right)$, slow $\left(N P Q_{\mathrm{S}}\right)$ and fast $\left(N P Q_{\mathrm{F}}\right)$ relaxation non-photochemical quenching over the duration of the experiment for shoots from control (circles), water deficit (triangles) and water logged (squares) seedlings grown under full sunlight (open symbols) and 50\% shade (closed symbols). Symbols represent a mean and vertical bars the standard deviation $(n=3)$. The arrows in panels (c) and (f) indicate when seedlings subjected to a water deficit (triangles), were re-watered. All $F_{\mathrm{v}}^{\mathrm{o}} / F_{\mathrm{m}}^{\mathrm{o}}$ measurements were taken between 11:00 and 14:00. 


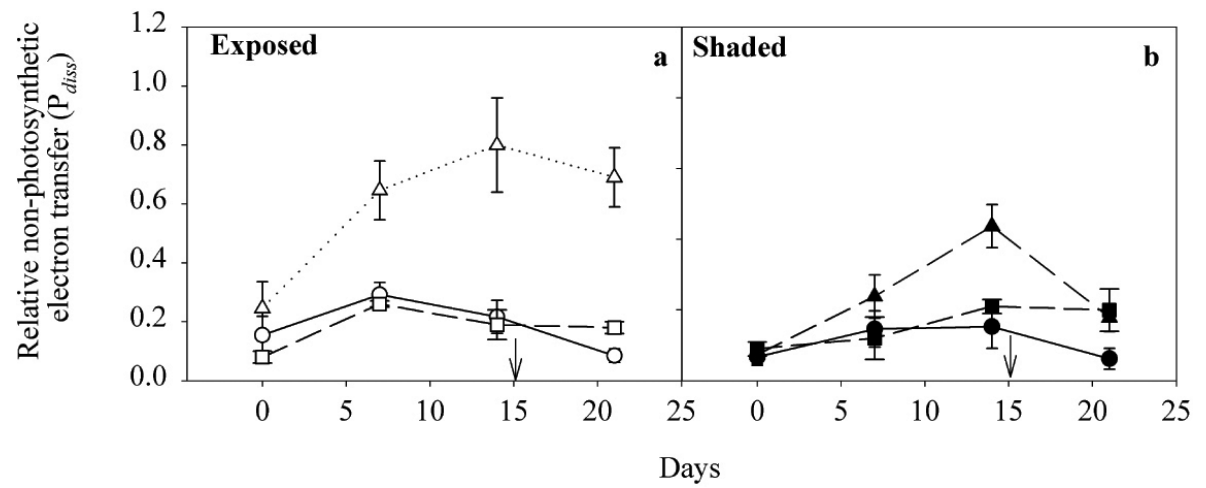

Figure 6. Changes in the relative contribution of non-photosynthetic electron transport in dissipating excess energy $\left(P_{\text {diss }}\right)$ over the duration of the experiment for shoots from control (circles), water deficit (triangles) and water logged (squares) seedlings grown under full sunlight (open symbols) and 50\% shade (closed symbols). Symbols represent a mean and the vertical bars the standard deviation $(n=3)$. The arrows in panels (a) and (b) indicate when seedlings subjected to a water deficit (triangles), were re-watered.

of a number of parameters associated with shoot water status (Figs. 2, 3, 4 and 6). Seedlings subjected to water deficits in the shade showed a smaller and more gradual increase in $\mathrm{P}_{\text {diss }}$, which did recover following re-watering.

In contrast, water logging under either exposed or shaded conditions resulted in a much smaller increase in $P_{\text {diss }}$ after 3 weeks (Fig. 6).

\section{DISCUSSION}

It is evident from this study that successful establishment of Sitka spruce seedlings using the current practice of out-planting in exposed sites may be undermined by reductions in photosynthesis, even under the relatively low irradiances associated with temperate climates. Photodamage to PSII was evident even in well-watered seedlings, as evident from the decrease in the dark-adapted photon yield and an increase in slow nonphotochemical quenching kinetics $\left(N P Q_{\mathrm{S}}\right)$. This has been associated with a decrease in $D 1$ protein regeneration in response to photo-oxidative damage in evergreens [1] and other species [33]. When grown under irradiances in excess of those that saturate photosynthesis, Sitka spruce seedlings did not exhibit any ability to increase $N P Q_{\mathrm{F}}$, which has been primarily linked to the dissipation of excess photons as heat via the xanthophyll cycle $[8,19]$. The inhibition of photosynthesis and photodamage of PSII in seedlings under high light was exacerbated by water deficits. In addition, the impact of water deficits on shoot water potential occurred earlier in fully exposed plants. It is also evident that a reduction in photosynthesis under waterlogged conditions, which typically shows a response comparable to that observed for plants exposed to a water deficit, such as a decline in $G_{\mathrm{s}}$ and hydraulic conductance (this study; [6]), was also substantially reduced under shaded conditions.

Whilst it has been suggested that the light environment is an important factor determining the establishment of seedlings under different management scenarios $[13,20]$, our results also show that interactions between light and water availability are important. Although these results suggest that the performance and establishment of seedlings would be enhanced under CCF systems representative of the light environments used in this study, interactions with other environmental factors, as well as the capacity for morphological adjustment [17, 31, 33], under different light regimes, should also be considered. Some studies have indicated shaded seedlings subjected to water deficits exhibited a lower shoot water potential, when compared to exposed seedlings, due to a greater depletion of soil moisture in the forest understory. Competition for water between plants may be exacerbated due to the lower root to shoot ratios of shaded plants [33].

The experimental procedure and seedling stock, used in this study were chosen to closely mimic the performance of outplanted commercial nursery seedling stock under conditions representative of clearfelled or CCF systems. The pre-treatment and physiological status of seedlings selected from the nursery may influence the performance of transplants in this study and under field conditions [24]. The extent to which this occurs may vary depending on nursery silvicultural procedures. Whilst these experiments were conducted in a glasshouse, the environmental conditions and plant material used were representative of many field situations and management practice scenarios. It is well known that the prevalent use of bare-root stock material would render seedlings more susceptible to water deficits as well as waterlogged conditions because of reduced root function, such as a decrease in hydraulic conductance ([27], this study). Whilst out-planting of bare-root stock in mounded windrows does potentially reduce the risk of water logging, particularly in clearfell/re-forested stands with wet mineral soils, waterlogged conditions are likely to occur in poorly drained afforested stands [22]. The possibility that outplanted seedlings may also experience water deficits, similar to those used in the current experiments, is also realistic. Depending on the soil type and time of year, fully exposed sites in Ireland may experience accumulated soil moisture deficits of $<75 \mathrm{~mm}$ for one to four periods greater than 10 days [4]. An accumulated soil moisture deficit of $<75 \mathrm{~mm}$ would be equivalent to a volumetric soil moisture content of $>0.2 \mathrm{~m}^{3} \mathrm{~m}^{-3}$ in this study. Such a deficit could occur within 5 to 9 days after the cessation of watering, depending on the extent of shade cover. In Ireland, water deficits are more common during April to July, particularly in the eastern and south-eastern low altitude areas, 
when potential evapotranspiration is highest [21]. The somewhat higher rate of soil moisture loss and the more rapid onset of water deficits in the current glasshouse experiments may be due to a higher evapo-transpirational loss under these conditions. Observed differences in the light microclimate under exposed or shaded conditions were similar to those recorded in exposed conditions or under CCF systems [13, 14].

Stomatal-related reductions in photosynthesis during periods of low water availability or high evaporative demand, as a consequence of reduced internal $\mathrm{CO}_{2}$ concentrations, have been well documented for numerous plant species [5, 9, 23]. However, various non-stomatal mechanisms, such as an increased rate of photorespiration [32] or photodamage [26], may also reduce photosynthetic performance under water deficits. The influences of stomatal versus non-stomatal limitations on photosynthesis during water deficits are difficult to untangle and may operate simultaneously [9]. In this study there was no evidence of stomatal limitation of photosynthesis via a reduction in $C_{\mathrm{i}}$. Our results suggest that the reduction in photosynthesis was primarily associated with an increase in non-photosynthetic electron flow, presumably photorespiration, in both the fully exposed and shaded treatments. This would be consistent with the proposal that photorespiration in $\mathrm{C}_{3}$ plants may be a significant alternative sink for light-induced electron flow [26, 29], reducing the possibility of photo inhibitory damage [32, 33]. There is also good evidence that both $G_{\mathrm{s}}$ and $G_{\mathrm{m}}$ are co-regulated and these can limit photosynthesis under water deficits [2, $10]$ for a range of plant species including conifers $[7,30]$. It is evident from this study and others [30] that $G_{\mathrm{m}}$ could limit photosynthesis to a comparable extent as $G_{\mathrm{S}}$ in seedlings exposed to water deficits. However, there are difficulties in the assessment of $G_{\mathrm{m}}$, when seedlings are exposed to extended periods of water deficits, due to low $C_{\mathrm{i}}$ and/or variable $\Gamma^{*}$ values [15]. Therefore more attention should be directed at reliable estimates of $G_{\mathrm{m}}$ before the significance of variations in $G_{\mathrm{m}}$ in tree seedling stock and its relationship to plant performance can be established.

\section{CONCLUSIONS}

The findings of this study support the practice of using container seedling stock, instead of bare-root stock, to improve seedling survival following out-planting, particularly during periods where water deficits could occur (April to July). It is evident that the establishment of Sitka spruce seedlings following under-planting could be improved under $\mathrm{CCF}$, compared to conventional systems, due to reduced photodamage and a faster recovery of photosynthesis under shaded conditions.

An ability to dissipate excess light or reduce photodamage may be an important physiological marker for the selection of seedling stock with enhanced performance in exposed sites with reduced water availability. Assessments of chlorophyll fluorescence, as a surrogate measure of plant performance, would assist in providing a more rapid and non-destructive evaluation of the suitability of seedling material for use in CCF or conventional systems. Clearly the development of an appropriate planting regime and management system requires information on soil type, drainage and windthrow risk, as well as the identification of species that are suitable for growing under different irradiances and periodic water deficits.

Acknowledgements: We would like to thank the National Council for Forest Research \& Development (COFORD) and the Environmental Protection Agency (EPA) for providing funding for this research, Conor O'Reilly (Department of Forestry, UCD) for providing the seedlings, Odhran O'Sullivan (Botany Department, UCD) for technical assistance and Germain Levieille (Botany Department, UCD) for translating the abstract.

\section{REFERENCES}

[1] Adams W.W., Zarter C.R., Ebbert V., Demming-Adams B., Photoprotective strategies of overwintering evergreens, BioScience 41 (2004) 41-49.

[2] Centritto M., Loreto F., Massacci A., Pietrini F., Villani M.C., Zacchini M., Improved growth and water use efficiency of cherry saplings under reduced light intensity, Ecol. Res. 15 (2000) 385-396.

[3] Centritto M., Loreto F., Chartzoulakis K., The use of low $\left[\mathrm{CO}_{2}\right]$ to estimate diffusional and non-diffusional limitations of photosynthetic capacity of salt-stressed olive saplings, Plant Cell Environ. 26 (2003) 585-594.

[4] Collins J.F., Larney F.J., Morgan M.A., Climate and soil management, in: Keane T., Collins J.F. (Eds.), Climate, Weather and Irish Agriculture, AGMET, Met Éireann, Dublin, 2004, pp. 239-256.

[5] Cornic G., Drought stress and high light effects on leaf photosynthesis, in: Baker N.R., Bowyer J.R. (Eds.), Photoinhibition of Photosynthesis - from molecular mechanisms to the field, BIOS Scientific Publishers Limited, Oxford, 1994, pp. 178-184.

[6] Coutts M.P., Effects of waterlogging on water relations of actively growing and dormant Sitka spruce seedlings, Ann. Bot. 47 (1981) 747-753.

[7] De Lucia E.H., Whitehead D., Clerwater M.J., The relative limitation of photosynthesis by mesophyll conductance in co-occurring species in a temperate rainforest dominated by the conifer Dacrydium cupressinum, Funct. Plant Biol. 30 (2003) 1197-1204.

[8] Demmig B., Winter K., Kruger A., Czygan F.C., Zeaxanthin and heat dissipation of excess light energy in Nerium oleander exposed to a combination of high light and excess light energy, Plant Physiol. 87 (1988) 17-24.

[9] Epron D., Dreyer E., Brèda M., Photosynthesis of oak trees [Quercus petraea (Matt.) Liebl.] during drought under filed conditions: diurnal coarse of net $\mathrm{CO}_{2}$ assimilation and photochemical efficiency of photosystem II, Plant Cell Environ. 15 (1992) 809-820.

[10] Flexas J., Bota J., Loreto F., Cornic G., Sharkey T.D., Diffusive and metabolic limitations to photosynthesis under drought and salinity in $\mathrm{C}_{3}$ plants, Plant Biol. 6 (2004) 269-279.

[11] Genty B., Briantaus J.M., Baker N.R., The relationship between quantum yield of photosynthetic electron transport and quenching of chlorophyll fluorescence, Biochim. Biophys. Acta 990 (1989) 87-92.

[12] Hale S.E., Light regime beneath Sitka spruce plantations in northern Britain: preliminary results, For. Ecol. Manage. 151 (2001) 61-66.

[13] Hale S.E., The effects of thinning intensity on the below-canopy light environment in a Sitka spruce plantation, For. Ecol. Manage. 179 (2003) 341-349.

[14] Hale S.E., Levy P.E., Gardiner B.A., Trade-offs between seedling growth, thinning and stand stability in Sitka spruce stands: a modelling analysis, For. Ecol. Manage. 187 (2004) 105-115.

[15] Harley P.C., Loreto F., Di Marco G., Sharkey T.D., Theoretical considerations when estimating the mesophyll conductance to $\mathrm{CO}_{2}$ flux by analysis of the response of photosynthesis to $\mathrm{CO}_{2}$, Plant Physiol. 98 (1992) 1429-1443. 
[16] Hoff C., Rambal S., An examination of the interaction between climate, soil and leaf area index in Quercus ilex ecosystem, Ann. For. Sci. 60 (2003) 153-161.

[17] Lambers H., Poorter H., Inherent variation in growth rate between higher plants: a search for physiological causes and ecological consequences, Adv. Ecol. Res. 23 (1992) 187-261.

[18] Leverenz J.W., Factors determining the nature of the light dosage response curve in leaves, in: Baker N.R., Bowyer J.R. (Eds.), Photoinhibition of Photosynthesis - from molecular mechanisms to the field, BIOS Scientific Publishers Ltd, Oxford, 1994 pp. 239-254.

[19] Li X.-P., Björkman O., Shih C., Grossman A.R., Rosenquest M., Jansson S., Niyogi K.K., A pigment-binding protein essential for regulation of photosynthetic light harvesting, Nature 403 (2000) 391-395.

[20] Lieffers V.J., Messier C., Stadt K.J., Gendron F., Comeau P.G., Predicting and managing light in the understory of boreal forests, Can. J. For. Res. 29 (1999) 796-811.

[21] Keane T., Collins J.F., Climate, weather and Irish agriculture, AGMET, Met Éireann, Dublin, 2004.

[22] Nieuwenhuis M., Wills J., Gardiner J., Sunström E., Keane M., The effect of soil cultivation methods on rooting depth of young Sitka spruce (Picea sitchensis (Bong.) Carr.) trees on wet mineral soils in Ireland, Forestry 76 (2003) 465-477.

[23] Osborne B., Black K., Lanigan G., Perks M., Clabby G., Survival on the exposed limestone pavement in the Burren: photosynthesis and water relations of three co-occuring plant species, Biology and Environment 103B (2003) 11-125.

[24] Perks M.P., Monaghan S., O'Reilly C., Osborne B.A., Mitchell D.T., Chlorophyll fluorescence characteristics, performance and survival of freshly lifted and cold stored Douglas fir seedlings, Ann. For. Sci. 58 (2001) 225-235.

[25] Powles S.B., Photoinhibition of photosynthesis induced by visable light, Ann. Rev. Plant Physiol. 35 (1984) 115-44.

[26] Powles S.B., Osmond C.B., Inhibition of the capacity and efficiency of photosynthesis in bean leaflets illuminated in a $\mathrm{CO}_{2}$-free atmosphere at low oxygen: a possible role for photorespiration, Aust. J. Plant Physiol. 5 (1978) 619-620.

[27] Pezeshki S.R., Chambers J.L., Stomatal and photosynthetic responses of sweet gum (Liquidambar styraciflua) to flooding, Can. J. For. Res. 15 (1985) 371-375.

[28] Ritchie G.A., Hinckley T.M., The pressure chamber as an instrument for ecological research, Adv. Ecol. Res. 9 (1975) 165-224.

[29] Sharkey T.D., Estimating the rate of photorespiration in leaves, Physiol. Plant. 73 (1988) 147-152.

[30] Stewart J.D., Zine el Abidine A., Bernier P.Y., Stomatal mesophyll limitations of photosynthesis in black spruce seedlings during multiple cycles of drought, Tree Physiol. 15 (1994) 57-64.

[31] Van Hees A.F.M., Clerkx A.P.P.M., Shading and root-shoot relations in saplings of silver birch, pedunculate oak and beech, For Ecol. Manage. 176 (2003) 439-448.

[32] Valentini R., Epron D., De Angelis P., Matteucci G., Dreyer E., In situ estimation of net $\mathrm{CO}_{2}$ assimilation, photosynthetic electron flow and photorespiration in Turkey oak (Q. cerris L.) leaves: diurnal cycles under different levels of water supply, Plant Cell Environ. 18 (1995) 631-640.

[33] Valladares F., Pearcy R.W., Drought can be more critical in the shade than the sun: a field study of carbon gain and photoinhibition in a Californian shrub during a dry El Nino year, Plant Cell Environ. 25 (2002) 749-759.

[34] Von Caemmerer S., Modelling $C_{3}$ photosynthesis, in: von Caemmerer S. (Ed.), Techniques in Plant Sciences No. 2, Biochemical models of leaf photosynthesis, CSIRO Publishing, Australia, 2000, pp. 29-70.

[35] Walters R.G., Horton P., Resolution of components of non-photochemical chlorophyll fluorescence quenching in barley leaves, Photosynth. Res. 27 (1991) 121-133.

[36] Wang Y.P., Jarvis P.G., Influence of shoot structure on the photosynthesis of Sitka spruce (Picea sitchensis), Funct. Ecol. 7 (1993) 433-451. 